\title{
Application of fertilizers and growth stimulants for growing chickpeas in the dry steppe zone of the Middle Volga region
}

\author{
Anton V. Novikov*, Nikolai A. Prosandeev, and Alexey N. Burunov \\ Samara State Agrarian University, 446442 Kinel, Samara region, Russia
}

\begin{abstract}
The results of the 2016-2017 studies are presented. Indicators of the crop structure, productivity and fodder values of chickpea varieties (Privo 1, Volgogradsky 10, Volzhanin) are determined. Different methods of crops treatment with growth stimulants Growth matrix, Megamix Profi, Aminokat + Raikat Development are described. The multifactorial experiment included two options of mineral nutrition (without and with fertilizers $\mathrm{N}_{12} \mathrm{P}_{52}$ (factor $\mathrm{A}$ ); three varieties of chickpeas: "Privo 1", "Volzhanin", "Volgogradsky 10" (factor B); two options of vegetation treatment: without and with treatment using Growth Matrix, Megamix Profi, Aminokat + Raikat Development (factor C). The studies have shown that all treatment options $\mathrm{f}$ increased productivity of chickpeas and crops quality. The maximum yield was obtained by applying $\mathrm{N}_{12} \mathrm{P}_{52}$ for Volzhanin variety treated with Megamix Profi and Aminokat + Raikat Development (2.19 t/ ha and 2.16 t/ha with a dry matter of 1.97-1.95 t/ha, digestible protein of 0.36-0.33 t/ ha and an exchange energy yield of 27.10-26.90 GJ/ha, respectively).
\end{abstract}

\section{Introduction}

The problem of insufficient amount of vegetable protein in feed is crucial. This problem can be solved by obtaining protein from legumes. They have a high feed value and improve the use of animal feed of other lowprotein crops [1-4].

Among all the leguminous crops, chickpeas are the most drought- and heat-resistant due to a high content of bound water in leaf tissues, their xeromorphic structure, pubescence, and the presence of organic acids [5]. Chickpea seeds contain $20.0-32.5 \%$ of crude protein, up to $8 \%$ of fat, $47-60 \%$ of starch. Carbohydrate content is several times higher than in soybean meal. Its proteins are balanced by the amino acid composition. They are the best by the number of basic essential amino acids (methionine and tryptophan).

Chickpea grain contains a significant amount of mineral salts. According to the content of selenium, it ranks first among all leguminous crops. The advantage of chickpeas over other leguminous crops is that it is less damaged by pests, has a standard bush with high attachment of lower beans, does not lie down; the beans do not crack or crumble. It can be removed by ordinary grain harvesters [6].

In agriculture, the main task is to increase the production of food and feed grain and improve its quality. The use of growth stimulants is one of the techniques for improving the crop cultivation technology. Plant growth regulators affect the productive use of mobile forms of minerals and increase the resistance of plants to stress, diseases and pests [7-9].

\section{Materials and methods}

The article aims to describe methods for increasing chickpea crops productivity in the dry steppe zone of the Middle Volga.

The research objectives are as follows:

- to assess productivity of different varieties of chickpeas depending on the use of Growth Matrix, Megamix Profi, Aminokat, Raikat Development at different levels of mineral nutrition;

- to assess the crops structure and the nutritional value of chickpeas.

The 2016-2017 field experiments were conducted at the "Zlak" LLC of Bolshekhernigov district of Samara region. The enterprise is located in the dry steppe zone of Samara region with an average annual amount of precipitation of $350 \mathrm{~mm}$. The sum of active temperatures is $2700-2800{ }^{\circ} \mathrm{C}$. The hydrothermal coefficient is 0.6 0.7 . Spring stocks of soil moisture are $100-120 \mathrm{~mm}$. The frost-free period lasts for 148-154 days.

The agricultural technology includes stubble cultivation, moldboard plowing, plowland harrowing, early spring cover harrowing and pre-sowing cultivation to a depth of 6-8 cm, $\mathrm{N}_{12} \mathrm{P}_{52}$ fertilizer application, traditional sowing, crops treatment with growth stimulants, crops treatment with insecticides.

The multifactorial experiment on different varieties of chickpeas and doses of mineral fertilizers included:

1) two options of mineral nutrition (without and with fertilizers $\mathrm{N}_{12} \mathrm{P}_{52}$ (factor $\mathrm{A}$ );

\footnotetext{
*Corresponding author: a.novikov63@mail.ru
} 
2) three varieties of chickpeas: "Privo 1", "Volzhanin", "Volgogradsky 10" (factor B);

3) two options of vegetation treatment: without and with treatment using Growth Matrix, Megamix Profi, Aminokat + Raikat Development (factor C).

There were 24 options and 96 land plots. 4

The studies were carried out taking into account the field experimental methods developed by B.A. Dospekhov (1985), the guidelines for conducting field experiments with fodder crops developed by the AllRussian Research Institute named after Williams (1987, 1997) and others.

\section{Results}

The phenological phases of plant development and the duration of interphase periods depend on abiotic factors or weather conditions; the main ones are heat and moisture. The cultivation conditions have a significant impact. The duration of the growing season for Privo 1 is 68-91 days, for Volzhanin - 71-101 days, for Volgogradsky-10 - 88-96 days. In the control option, the full ripeness of Privo 1 was observed on the $73^{\text {rd }}$ day of sowing in 2016, and on the $70^{\text {th }}$ day of sowing in 2017; when applying $\mathrm{N}_{12} \mathrm{P}$ Volgogradsky 10 , it was observed on the $79^{\text {th }}$ and $76^{\text {th }}$ days, respectively. A similar pattern was observed for Volzhanin and Volgogradsky 10. The vegetation period for Volzhanin was 77-81 days, for Volgogradsky 10 - 71-79 days.

The analysis of the crops structure is an important technique for assessing the development of cultivated plants; it allows us to establish patterns of crop formation and trace its dependence on a variety of environmental factors, effects of chemicals, or extreme weather conditions. The main components of the crops structure characterizing the level of development of agrophytocenosis of leguminous crops are density of plants, the number of beans per 1 plant, the number of seeds in one bean and the weight of 1000 seeds.

Table 1. Chickpea crop structure depending on the use of fertilizers and growth stimulants, 2016-2017, average value.

\begin{tabular}{|c|c|c|c|c|c|c|}
\hline \multicolumn{2}{|c|}{ Option } & \multirow{2}{*}{$\begin{array}{l}\text { Number of } \\
\text { plants, pcs / } \\
\mathrm{m}^{2}\end{array}$} & \multirow{2}{*}{$\begin{array}{l}\text { Number of } \\
\text { beans per } 1 \\
\text { plant, pcs. }\end{array}$} & \multirow{2}{*}{$\begin{array}{l}\text { Number of } \\
\text { seeds in one } \\
\text { bean, pcs. }\end{array}$} & \multirow{2}{*}{$\begin{array}{l}\text { Mass of } \\
1000 \\
\text { seeds, } g\end{array}$} & \multirow{2}{*}{$\begin{array}{c}\text { Productivity, } \\
\text { t/ha }\end{array}$} \\
\hline Variety & vegetation treatment & & & & & \\
\hline \multicolumn{7}{|c|}{ Control option (without fertilizers) } \\
\hline \multirow{4}{*}{ Privo 1} & control & 26.0 & 20.0 & 1.1 & 274.9 & 1.52 \\
\hline & Growth matrix & 27.8 & 21.2 & 1.1 & 274.6 & 1.77 \\
\hline & Megamix Profi & 27.5 & 22.4 & 1.1 & 290.3 & 1.98 \\
\hline & $\begin{array}{l}\text { Aminokat + Raikat } \\
\text { Development }\end{array}$ & 28.5 & 20.8 & 1.2 & 283.8 & 1.99 \\
\hline \multirow{4}{*}{ Volzhanin } & control & 33.0 & 20.8 & 1.1 & 303.4 & 2.18 \\
\hline & Growth matrix & 35.0 & 21.3 & 1.1 & 309.0 & 2.42 \\
\hline & Megamix Profi & 35.0 & 22.2 & 1.1 & 296.6 & 2.47 \\
\hline & $\begin{array}{l}\text { Aminokat + Raikat } \\
\text { Development }\end{array}$ & 34.5 & 22,2 & 1.0 & 308.3 & 2.36 \\
\hline \multirow{4}{*}{ Volgogradsky 10} & control & 33.0 & 18.9 & 1.1 & 289.3 & 1.83 \\
\hline & Growth matrix & 34.0 & 19.4 & 1.0 & 290.9 & 1.94 \\
\hline & Megamix Profi & 35.0 & 19.4 & 1.0 & 289.7 & 2.05 \\
\hline & $\begin{array}{l}\text { Aminokat + Raikat } \\
\text { Development }\end{array}$ & 36.0 & 19.1 & 1.1 & 282.0 & 2.06 \\
\hline \multicolumn{7}{|c|}{ Application of $\mathrm{N}_{12} \mathrm{P}_{52}$} \\
\hline \multirow{4}{*}{ Privo 1} & control & 33,0 & 27.0 & 1.1 & 265.6 & 2.49 \\
\hline & Growth matrix & 34.5 & 28.7 & 1.1 & 267.3 & 2.78 \\
\hline & Megamix Profi & 36.5 & 27.4 & 1.1 & 284.6 & 3.00 \\
\hline & $\begin{array}{l}\text { Aminokat + Raikat } \\
\text { Development }\end{array}$ & 37.3 & 26.9 & 1.1 & 287.9 & 3.03 \\
\hline \multirow{4}{*}{ Volzhanin } & control & 37.5 & 23.2 & 1.0 & 336.3 & 2.90 \\
\hline & Growth matrix & 39.5 & 24.0 & 1.0 & 337.7 & 3.16 \\
\hline & Megamix Profi & 39.5 & 26.1 & 1.0 & 344.2 & 3.61 \\
\hline & $\begin{array}{l}\text { Aminokat + Raikat } \\
\text { Development }\end{array}$ & 40.8 & 26.3 & 1.0 & 325.1 & 3.48 \\
\hline \multirow{4}{*}{ Volgogradsky 10} & control & 38.2 & 22.0 & 1.0 & 292.0 & 2.48 \\
\hline & Growth matrix & 40.3 & 22.9 & 1.0 & 298.0 & 2.76 \\
\hline & Megamix Profi & 40.3 & 23.5 & 1.0 & 314.9 & 3.02 \\
\hline & $\begin{array}{l}\text { Aminokat + Raikat } \\
\text { Development }\end{array}$ & 39.3 & 23.6 & 1.0 & 307.6 & 2.90 \\
\hline
\end{tabular}


The analysis of the crops structure identified the positive effect of fertilizers and growth stimulants. The density of plants increases with increasing mineral nutrition of plants. For Volzhanin, when applying Aminokat + Raikat, Development without the use of fertilizers, the number of plants was $34.5 \mathrm{pcs} / \mathrm{m}^{2}$; using $\mathrm{N}_{12} \mathrm{P}_{52}$, the number of plants was $40.8 \mathrm{pcs} / \mathrm{m}^{2}$ (Table 1 ). A similar pattern was observed for other two varieties.

The number of beans and seeds in one bean is determined by biological characteristics of the crop; however, under the influence of weather and growing conditions, they can vary between 18.9-28.7 pcs (Table 1 ). When using fertilizers, a larger number of beans was formed. With an increase in the level of mineral nutrition, the mass of 1000 seeds increases. Without the use of fertilizers, it was 274.6-309.0 g; in the second option, it was 265.6-344.2 g. The largest seeds were observed in the Volzhanin variety.

The maximum yield of chickpeas was observed when applying $\mathrm{N}_{12} \mathrm{P}_{52}$ for Volzhanin when treating seeds with
Megamix Profi (3.61 t $/$ ha compared to the control yiled equal to $0.71 \mathrm{t} / \mathrm{ha}$ (Table 1). Similar indicators of biological productivity were observed for the same variety when treating crops with Aminokat + Raikat Development and Growth matrix (3.48 and 3.16 t/ha compared to the control yield of $0.58 \mathrm{t} / \mathrm{ha}$ and $0.26 \mathrm{t} / \mathrm{ha}$, respectively).

The most important indicator of the use of growth stimulants and other agricultural techniques, is the crops yield. The yield indicators for chickpeas determined by the use of fertilizers are presented in Table 2.

According to the data obtained in 2016, the following patterns were identified. Chickpea productivity was $1.10-2.66 \mathrm{t} / \mathrm{ha}$ (Table 2). There is a tendency to increase the yield of chickpeas using fertilizers. Due to the application of $\mathrm{N}_{12} \mathrm{P}_{52}$, the Privo 1 variety treated with Growth Matrix increased the yield by $0.65 \mathrm{t} / \mathrm{ha}$ compared to the control option without fertilizing. This pattern was observed in all other variants. Volzhanin was the most responsive to fertilizers.

Table 2. Chickpea productivity depending on the application of fertilizers and growth stimulants, 2016-2017, t/ha.

\begin{tabular}{|c|c|c|c|c|}
\hline \multicolumn{2}{|r|}{ Option } & \multicolumn{3}{|c|}{ Productivity, t/ha } \\
\hline Variety & vegetation treatment & 2016 & 2017 & average \\
\hline \multicolumn{5}{|c|}{ Control option (without fertilizers) } \\
\hline \multirow[t]{4}{*}{ Privo 1} & control & 1.10 & 1.31 & 1.21 \\
\hline & Growth matrix & 1.14 & 1.35 & 1.25 \\
\hline & Megamix Profi & 1.19 & 1.41 & 1.30 \\
\hline & Aminokat + Raikat Development & 1.17 & 1.40 & 1.29 \\
\hline \multirow[t]{4}{*}{ Volzhanin } & control & 1.45 & 1.40 & 1.43 \\
\hline & Growth matrix & 1.54 & 1.42 & 1.48 \\
\hline & Megamix Profi & 1.63 & 1.46 & 1.55 \\
\hline & Aminokat + Raikat Development & 1.52 & 1.48 & 1.50 \\
\hline \multirow[t]{4}{*}{ Volgogradsky 10} & control & 1.18 & 1.26 & 1.22 \\
\hline & Growth matrix & 1.21 & 1.28 & 1.25 \\
\hline & Megamix Profi & 1.17 & 1.33 & 1.25 \\
\hline & Aminokat + Raikat Development & 1.19 & 1.36 & 1.28 \\
\hline \multicolumn{5}{|c|}{ Application of $\mathrm{N}_{12} \mathrm{P}_{52}$} \\
\hline \multirow[t]{4}{*}{ Privo 1} & control & 1.65 & 1.47 & 1.56 \\
\hline & Growth matrix & 1.79 & 1.49 & 1.64 \\
\hline & Megamix Profi & 1.86 & 1.51 & 1.69 \\
\hline & Aminokat + Raikat Development & 1.94 & 1.56 & 1.75 \\
\hline \multirow[t]{4}{*}{ Volzhanin } & control & 2.23 & 1.63 & 1.93 \\
\hline & Growth matrix & 2.48 & 1.66 & 2.07 \\
\hline & Megamix Profi & 2.66 & 1.72 & 2.19 \\
\hline & Aminokat + Raikat Development & 2.60 & 1.71 & 2.16 \\
\hline \multirow[t]{4}{*}{ Volgogradsky 10} & control & 1.58 & 1.42 & 1.50 \\
\hline & Growth matrix & 1.64 & 1.43 & 1.54 \\
\hline & Megamix Profi & 1.66 & 1.48 & 1.57 \\
\hline & Aminokat + Raikat Development & 1.61 & 1.47 & 1.54 \\
\hline
\end{tabular}

The maximum yield increase for this variety is 1.02 $\mathrm{t} /$ ha due to the application of $\mathrm{N}_{12} \mathrm{P}_{52}$, whereas, for Privo 1 , an increase is $0.69 \mathrm{t} / \mathrm{ha}$; for Volgogradsky, an increase is $10-0.45 \mathrm{t} / \mathrm{ha}$.

Vegetation treatment increases productivity. The best options for Megamix Profi and Aminokat + Raikat
Development. In the option without fertilizing but applying Megamix Profi, the yield is $1.63 \mathrm{t} / \mathrm{ha}$, exceeding crop yields for two other varieties by 0.09 and $0.11 \mathrm{t} / \mathrm{ha}$ respectively.

When applying $\mathrm{N}_{12} \mathrm{P}_{52}$, the maximum yield was observed in Volzhanin in the option including the 
application of Megamix Profi and Aminokat + Raikat Razvit (2.66 t/ha and $2.60 \mathrm{t} / \mathrm{ha}$, respectively). Privo 1 and Volgogradsky 10 have a yield lower by 0.72 and 0.94 $\mathrm{t} / \mathrm{ha}$ than Volzhanin. This can be seen at all levels of mineral nutrition.

In 2017 , chickpea productivity was $1.31-1.48 \mathrm{t} / \mathrm{ha}$ in the control option without fertilizer application and 1.47$1.72 \mathrm{t} / \mathrm{ha}$ when applying $\mathrm{N}_{12} \mathrm{P}_{52}$ (Table 2). There is an obvious increase in the yield of chickpeas with an increase in mineral nutrition.

Among the varieties under study Volzhanin has a higher productivity. When applying $\mathrm{N}_{12} \mathrm{P}_{52}$, the average yield in all the options was $1.68 \mathrm{t} / \mathrm{ha}$; for Privo 1 and Volgogradsky 10 , it was $1.51 \mathrm{t} / \mathrm{ha}$ and $1.45 \mathrm{t} / \mathrm{ha}$, respectively. The maximum yield in the control option was observed in Volzhanin (1.55 t/ha); when applying $\mathrm{N}_{12} \mathrm{P}_{52}$, it was $2.19 \mathrm{t} / \mathrm{ha}$.

On average, over the two years of research, the positive effect of fertilizers and growth stimulants was observed in Growth matrix, Megamix Profi and Aminokat + Raikat Development. They positively affect the growth dynamics of chickpea productivity. The most productive variety was Volzhanin whose productivity exceeded that of Privo 1 and Volgogradsky 10 by 0.43 $\mathrm{t} /$ ha and $0.55 \mathrm{t} / \mathrm{ha}$, respectively when applying $\mathrm{N}_{12} \mathrm{P}_{52}$.

The nutritional benefits are the dry matter content, feed units and fodder protein units, digestible protein and metabolic energy. The yield of digestible protein shows the effect of fertilizers and growth stimulants. IN the control option, the yield of digestible protein was 0.17 $0.24 \mathrm{t} / \mathrm{ha}$; when applying $\mathrm{N}_{12} \mathrm{P}_{52}$, it was $0.23-0.36 \mathrm{t} / \mathrm{ha}$ (Table 3).

The highest yield of metabolic energy was observed in Volzhanin due to the increased mineral nutrition when treating crops with Aminokat + Raikat Razvit and Megamix Profi (26.90- 27.10 GJ, respectively).

Table 3. The nutritional benefits of the chickpea crop depending on the application of growth stimulants and fertilizers, 2016-2017

\begin{tabular}{|c|c|c|c|c|c|c|c|}
\hline \multicolumn{2}{|c|}{ Option } & \multicolumn{5}{|c|}{ Per 1 ha } & \multirow[b]{2}{*}{$\mathrm{PP} / \mathrm{KE}, \mathrm{g}$} \\
\hline Variety & Vegetation treatment & $\begin{array}{c}\text { dry } \\
\text { matter, } \\
\text { t/ha }\end{array}$ & $\begin{array}{l}\text { protein, } \\
\text { t/ha }\end{array}$ & $\begin{array}{c}\text { feed } \\
\text { units, } \\
\text { thousan } \\
\text { d/ha } \\
\end{array}$ & $\begin{array}{c}\text { KPI, } \\
\text { thousan } \\
\text { d/ha }\end{array}$ & $\begin{array}{c}\text { exchange } \\
\text { energy, } \\
\text { GJ/ha }\end{array}$ & \\
\hline \multicolumn{8}{|c|}{ Control option (without fertilizers) } \\
\hline \multirow{4}{*}{ Privo 1} & control & 1.09 & 0.17 & 1.43 & 1.58 & 14.98 & 120.24 \\
\hline & Growth matrix & 1.13 & 0.19 & 1.50 & 1.67 & 15.63 & 123.51 \\
\hline & Megamix Profi & 1.18 & 0.19 & 1.55 & 1.72 & 16.27 & 120.07 \\
\hline & $\begin{array}{l}\text { Aminokat + Raikat } \\
\text { Development }\end{array}$ & 1.16 & 0.20 & 1.53 & 1.73 & 15.97 & 125.19 \\
\hline \multirow{4}{*}{ Volzhanin } & control & 1.29 & 0.22 & 1.71 & 1.96 & 17.67 & 129.65 \\
\hline & Growth matrix & 1.34 & 0.23 & 1.76 & 2.02 & 18.38 & 129.63 \\
\hline & Megamix Profi & 1.40 & 0.24 & 1.85 & 2.10 & 19.24 & 127.06 \\
\hline & $\begin{array}{l}\text { Aminokat + Raikat } \\
\text { Development }\end{array}$ & 1.36 & 0.23 & 1.79 & 2.04 & 18.73 & 127.54 \\
\hline \multirow{4}{*}{ Volgogradsky 10} & control & 1.11 & 0.18 & 1.46 & 1.65 & 15.23 & 126.26 \\
\hline & Growth matrix & 1.13 & 0.19 & 1.50 & 1.70 & 15.56 & 127.56 \\
\hline & Megamix Profi & 1.14 & 0.18 & 1.49 & 1.67 & 15.72 & 122.67 \\
\hline & $\begin{array}{l}\text { Aminokat + Raikat } \\
\text { Development }\end{array}$ & 1.16 & 0.19 & 1.53 & 1.72 & 15.94 & 124.24 \\
\hline \multicolumn{8}{|c|}{ Application of $\mathbf{N}_{\mathbf{1 2}} \mathbf{P}_{52}$} \\
\hline \multirow{4}{*}{ Privo 1} & control & 1.41 & 0,23 & 1.87 & 2.08 & 19.53 & 122.36 \\
\hline & Growth matrix & 1.48 & 0.24 & 1.96 & 2.19 & 20.54 & 123.50 \\
\hline & Megamix Profi & 1.52 & 0.26 & 2.01 & 2.29 & 21.05 & 127.78 \\
\hline & $\begin{array}{l}\text { Aminokat + Raikat } \\
\text { Development }\end{array}$ & 1.58 & 0.26 & 2.09 & 2.33 & 21.92 & 123.67 \\
\hline \multirow{4}{*}{ Volzhanin } & control & 1.74 & 0.29 & 2.30 & 2.57 & 24.05 & 123.94 \\
\hline & Growth matrix & 1.86 & 0.30 & 2.45 & 2.72 & 25.68 & 123.01 \\
\hline & Megamix Profi & 1.97 & 0.36 & 2.60 & 3.08 & 27.10 & 137.39 \\
\hline & $\begin{array}{l}\text { Aminokat + Raikat } \\
\text { Development }\end{array}$ & 1.95 & 0.33 & 2.57 & 2.91 & 26.90 & 128.46 \\
\hline \multirow{4}{*}{ Volgogradsky 10} & control & 1.36 & 0.23 & 1.80 & 2.01 & 18.75 & 123.49 \\
\hline & Growth matrix & 1.40 & 0.24 & 1.83 & 2.11 & 19.11 & 130.09 \\
\hline & Megamix Profi & 1.42 & 0.25 & 1.88 & 2.19 & 19.59 & 134.11 \\
\hline & $\begin{array}{l}\text { Aminokat + Raikat } \\
\text { Development }\end{array}$ & 1.39 & 0.23 & 1.83 & 2.07 & 19.12 & 126.21 \\
\hline
\end{tabular}


The analysis of fodder protein units allows us to conclude that the use of growth stimulants and mineral fertilizers increase this indicator; the Volzhanin variety is more responsive to fertilizing than the Volgogradsky 10 and Privo 1 varieties. When applying $\mathrm{N}_{12} \mathrm{P}_{52}$ for Volzhanin, the feed units were 2.91-3.08 thousand/ha when treating crops with Aminokat + Raikat Razvit and Megamix Profi.

\section{Conclusion}

The field experiments on the influence of different methods of chickpea crops treatment (Privo 1, Volzhanin, Volgogradsky 10) found that the use of growth stimulants and mineral fertilizers have a positive effect on the yield. The maximum yield was obtained when applying $\mathrm{N}_{12} \mathrm{P}_{52}$ for Volzhanin when treating crops with Megamix Profi during the vegetation period (3.61 $\mathrm{t} / \mathrm{ha}$ compared to the control yield of $0.71 \mathrm{t} / \mathrm{ha} /$ ).

Similar indicators of biological productivity were observed for the same variety when treating crops with Aminokat + Raikat Development and Growth matrix (3.48 and $3.16 \mathrm{t} / \mathrm{ha}$ compared to the control yield of 0.58 t/ha and $0.26 \mathrm{t} / \mathrm{ha}$, respectively). High yields were obtained when applying $\mathrm{N}_{12} \mathrm{P}_{52}$ for Volzhanin and treating crops with Megamix Profi and Aminokat + Raikat Razvit (2.19 t/ha and 2.16 t/ha, respectively).

\section{References}

1. V.I. Zotikov, T.S. Naumkina, B.C. Sidorenko, The current state of the industry of leguminous and cereal crops in Russia Bulletin of Oryol SAU 1, 1417 (2006)

2. S. I. Kononenko, Yu. I. Levakhin, A. G. Meshcheryakov, A. M. Ispanova, Peas and chickpeas of different varieties in feed production Zootechnical science of Belarus 50(2), 3-11 (2015)
3. A.G. Meshcheryakov, V.A. Shakhov, V.L. Korolev, V.A. Dotsenko, Comparative evaluation of the nutritional value of pea and chickpea grains under drought conditions Bulletin of Orenburg State Agrarian University 5, 180-183 (2014)

4. V.V. Semyonov, S. I. Kononenko, I. S. Kononenko, Nutrition and amino acid composition of sorghum grains used in animal feeding in Collection of scientific papers of Stavropol Scientific Research Institute of Animal Husbandry and feed production 1(4-1), 86-88 (2011)

5. N.I. Germantseva, Chickpea as a variety of arid agriculture (Saratov, 2011)

6. A.G. Meshcheryakov, G. I. Levakhin, A. A. Ziganshin, V. A. Dotsenko et al., Qualitative characteristics of protein and fiber of the main feed means of the diets of the steppe zone of the Southern Urals Bulletin of Orenburg State Agrarian University 3, 264-267 (2009)

7. V.G. Vasin, O.N. Lysak, O.V. Vershinina, Techniques for pre-sowing treatment of chickpea seeds and crops with growth biostimulants, in Actual problems of agrarian science and ways to solve them: collection of scientific papers (State Agricultural Academy, Kinel, 2015)

8. V.G. Vasin, E.I. Makarova, V.V. Rakitina, Productivity of Privo 1 chickpeas when applying growth regulators at different levels of mineral nutrition in the conditions of the forest-steppe of the Middle Volga region, in Actual problems of agricultural science and their solutions: a collection of scientific papers (RICA of the State Agricultural Academy, Kinel, 2015)

9. A.I. Erokhin, Efficiency of biological preparations for the pre-sowing treatment of seeds and vegetative plants of leguminous plants Legumes and cereals 1(13), 29 (2015) 